F. Reprod. Fert. (1966) 12, 395-397

BRIEF COMMUNICATION

\title{
THE EFFECT OF REDUCING THE NUMBER OF EMBRYOS DURING EARLY STAGES OF GESTATION ON THE MAINTENANCE OF PREGNANCY IN THE PIG
}

\author{
C. POLGE, L. E. A. ROWSON ANd M. C. GHANG* \\ A.R.C. Unit of Reproductive Physiology and Biochemistry, \\ Animal Research Station, 307 Huntingdon Road, Cambridge
}

(Received 5th April 1966)

The number of embryos has been experimentally reduced during early stages of gestation in the pig by means of partial hysterectomy (du Mesnil du Buisson \& Rombauts, 1963). Pregnancy is maintained in animals in which only one embryo remains so long as all the uterus is removed except that portion occupied by the embryo. By contrast, if the embryos are confined to one of the uterine horns, the unilateral pregnancy so established is not maintained unless the non-pregnant horn is removed before the 14th day of the oestrous cycle (du Mesnil du Buisson, 1961). The absence of embryos in one horn leads to regression of corpora lutea and thus complete failure of pregnancy at an early stage. These observations suggest that the presence of embryos in a large part of both uterine horns is necessary to establish and maintain pregnancy.

The normal number of ovulations in the pig is between twelve and eighteen. Fertilization rate is generally high (Hancock, 1957) and although some embryonic loss may occur during the first few weeks of gestation, there is usually a large number of embryos distributed within the uterus by the 14th day of the cycle. Ovulation rate from the two ovaries may be uneven, but embryonic migration within the uterus occurs (Corner, 1921; Dziuk, Polge \& Rowson, 1964) and establishes an even number of blastocysts in both uterine horns. Thus by the 13th to 18th day of pregnancy, blastocysts have elongated and occupy almost the entire length of the uterus (Perry \& Rowlands, 1962). It would be of interest to know how many embryos are necessary in order to establish and maintain pregnancy in normal intact animals.

During the course of experiments in which eggs were being collected from pigs soon after mating in order to examine early stages of embryonic development, there was a number of animals in which complete recovery of the eggs was not achieved. Thus a variable number of fertilized or unfertilized eggs was left behind in the Fallopian tubes. The effect on subsequent establishment of pregnancy or return to oestrus was recorded.

The experimental animals were twenty-nine cross-bred Large White gilts.

* The Worcester Foundation for Experimental Biology, Shrewsbury, Massachusetts, U.S.A. 
They were mated during the 1st or 2nd day of oestrus and eggs were collected 1 or 2 days later. At the time of operation, animals were anaesthetized by intravenous pentobarbitone sodium and maintained during surgery by cyclopropane. The reproductive tract was exposed via mid-ventral laparotomy. Eggs were collected from the Fallopian tubes by inserting a glass cannula into the fimbriated end and injecting 20 to $40 \mathrm{ml}$ of saline into the lower part of the oviduct just above the utero-tubal junction. The flushings were collected via the cannula into curved glass bowls and the number of eggs recovered was

TABLE 1

EFFECT OF REDUCED NUMBERS OF FERTILIZED OR UNFERTILIZED EGGS ON PREGNANCY AND LENGTH OF OESTROUS CYCLE IN THE PIG

\begin{tabular}{c|c|c|c|c|c}
\hline $\begin{array}{c}\text { Gilt } \\
\text { No. }\end{array}$ & $\begin{array}{c}\text { No. of } \\
\text { corpora } \\
\text { lutea }\end{array}$ & $\begin{array}{c}\text { No. of } \\
\text { eggs } \\
\text { recovered }\end{array}$ & $\begin{array}{c}\text { Recovered eggs } \\
\text { fertilized }(F) \text { or } \\
\text { unfertilized }(U)\end{array}$ & $\begin{array}{c}\text { No. of eggs } \\
\text { remaining }\end{array}$ & $\begin{array}{c}\text { Subsequent length } \\
\text { of } \\
\text { oestrous cycle } \\
\text { (days) }\end{array}$ \\
\hline 60 & 15 & 6 & $\mathrm{U}$ & 9 & 22 \\
63 & 15 & 8 & $\mathrm{U}$ & 7 & 21 \\
64 & 16 & 10 & $\mathrm{U}$ & 6 & 19 \\
13 & 17 & 11 & $\mathrm{U}$ & 6 & 21 \\
50 & 15 & 10 & $\mathrm{U}$ & 5 & 21 \\
7 & 16 & 13 & $\mathrm{U}$ & 3 & 20 \\
26 & 14 & 11 & $\mathrm{U}$ & 3 & 20 \\
35 & 13 & 10 & $\mathrm{U}$ & 3 & 20 \\
32 & 13 & 11 & $\mathrm{U}$ & 2 & 21 \\
59 & 12 & 11 & $\mathrm{U}$ & 1 & 22 \\
40 & 14 & 5 & $\mathrm{~F}$ & 9 & Pregnant \\
57 & 15 & 8 & $\mathrm{~F}$ & 7 & Pregnant \\
25 & 14 & 7 & $\mathrm{~F}$ & 7 & Pregnant \\
28 & 12 & 6 & $\mathrm{~F}$ & 6 & Pregnant \\
19 & 10 & 5 & $\mathrm{~F}$ & 5 & 25 \\
27 & 14 & 10 & $\mathrm{~F}$ & 4 & Pregnant \\
73 & 14 & 10 & $\mathrm{~F}$ & 4 & 27 \\
45 & 14 & 10 & $\mathrm{~F}$ & 4 & 27 \\
43 & 10 & 6 & $\mathrm{~F}$ & 4 & 27 \\
42 & 15 & 12 & $\mathrm{~F}$ & 3 & 25 \\
14 & 13 & 10 & $\mathrm{~F}$ & 3 & 26 \\
66 & 11 & 9 & $\mathrm{~F}$ & 2 & 30 \\
20 & 13 & 12 & $\mathrm{~F}$ & 1 & 26 \\
11 & 12 & 11 & $\mathrm{~F}$ & 1 & 27 \\
23 & 10 & 9 & $\mathrm{~F}$ & 1 & 27 \\
68 & 11 & 10 & $\mathrm{~F}$ & 1 & 30 \\
49 & 15 & 14 & $\mathrm{~F}$ & 1 & 24 \\
39 & 8 & 7 & $\mathrm{~F}$ & 1 & 20 \\
8 & 13 & 13 & $\mathrm{~F}$ & 0 & 21 \\
\hline & & & & & \\
\hline
\end{tabular}

recorded. A careful count was also made of the number of corpora lutea on each ovary. The eggs were later fixed, stained and examined for evidence of fertilization. Following recovery from the operation the gilts were tested regularly with a vasectomized boar to determine the time of return to oestrus.

The number of corpora lutea in each animal, the number of fertilized or unfertilized eggs recovered or remaining in the oviducts, and the subsequent cycle length are shown in Table 1 . There were ten animals in which the eggs were unfertilized and all these returned to oestrus 19 to 22 days following the previous oestrus. By contrast, of the nineteen animals from which fertilized eggs 
were recovered, there were only two which returned to oestrus at the expected normal cycle length of 21 days (No. 8 in which complete recovery of eggs was obtained and No. 39 in which one fertilized egg was not recovered). All the other animals were either pregnant or exhibited a significantly extended cycle. In the five animals which became pregnant, the number of fertilized eggs remaining was between four and nine. The number of fertilized eggs remaining in the majority of animals which had an extended cycle was four or less.

These results suggest that more than four embryos are required in the pig in order to establish and maintain pregnancy. It is of interest, however, that even one embryo may significantly affect the cycle length and extend it by about 6 days. Since these animals were not killed but were allowed to return to oestrus, it cannot be established at what time luteal regression occurred or whether it occurred at the same time in both ovaries. It seems likely, however, that four embryos or less are unable to overcome completely the luteolytic influence normally exerted by a non-pregnant uterus. Evidence from experiments involving partial hysterectomy in non-pregnant pigs has shown that when more than about one-quarter of the uterus is left, luteal regression will occur, but removal of all of the uterus results in maintenance of the corpora lutea (du Mesnil du Buisson, 1960; Anderson, Butcher \& Melampy, 1961). It is possible that when fewer than four embryos are present within the uterus during the 2nd to 3rd week of pregnancy, more than one-quarter of its total length is not occupied by the trophoblasts, and thus the corpora lutea are not maintained and pregnancy is terminated.

From the practical point of view a mechanism in polytocous species which results in an early failure of pregnancy when litter size is abnormally low is an obvious advantage; animals can mate again before a complete gestation length has ensued. Similarly it is suggested that exceptionally low litter sizes in pigs at the time of parturition must result from embryonic losses occurring relatively late in pregnancy.

\section{REFERENCES}

Anderson, L. L., Butcher, R. L. \& Melampy, R. M. (1961) Subtotal hysterectomy and ovarian function in gilts. Endocrinology, 69, 571 .

Corner, G. W. (1921) Internal migration of the ovum. Bull. Johns Hopkins Hosp. 32, 78.

Du Buisson, F. Du M. (1960) Régression unilaterale des corps jaunes après hystérectomie partielle chez la truie. Annls Biol. anim. Biochim. Biophys. 1, 105.

Du Bursson, F. Du M. (1961) Possibilité d'un functionnement dissemblable des ovaires pendant la gestation chez la truie. C. r. hebd. Séanc. Acad. Sci., Paris, 253, 727.

Du Buisson, Du M. \& Rombauts. P. (1963) Réduction expérimentale du nombre de foetus au cours de la gestation de la truie et maintien des corps jaunes. Annls Biol. anim. Biochim. Biophys. 3, 445.

Dzruk, P. J., Polge, C. \& Rowson, L. E. (1964) Intra-uterine migration and mixing of embryos in swine following egg transfer. F. Anim. Sci. 23, 37.

Hancock, J. L. (1957) The fertility of natural and of artificial mating in the pig. Stud. Fert. 9, 146.

Perry, J. S. \& Rowlands, I. W. (1962) Early pregnancy in the pig. F. Reprod. Fert. 4, 175. 